\section{EMBRYRIDDLE}

Aeronautical University

SCHOLARLY COMMONS
Journal of Aviation/Aerospace

Education \& Research

Volume 3

Number 1 JAAER Fall 1992

Article 1

Fall 1992

\title{
A Comparison between Airline Cost Structure Pre- and Post- Deregulation
}

Atef Ghobrial Ph.D.

Follow this and additional works at: https://commons.erau.edu/jaaer

\section{Scholarly Commons Citation}

Ghobrial, A. (1992). A Comparison between Airline Cost Structure Pre- and Post-Deregulation. Journal of Aviation/Aerospace Education \& Research, 3(1). https://doi.org/10.15394/jaaer.1992.1080

This Article is brought to you for free and open access by the Journals at Scholarly Commons. It has been accepted for inclusion in Journal of Aviation/Aerospace Education \& Research by an authorized administrator of Scholarly Commons. For more information, please contact commons@erau.edu. 


\title{
A COMPARISON BETWEEN AIRLINE COST STRUCTURE PRE-AND POST-DEREGULATION
}

\author{
Atef Ghobrial, Ph.D.
}

\begin{abstract}
This study compares the pre- and post-deregulation changes in the cost structure of two carrier groups: majors and nationals. A dummy-variable model was estimated, using data from 1970 to 1988. The results suggest that while the percentage of total cost incurred in maintenance decreased, costs of promotion, sales, and advertisement increased. It also appears that the percentage of some cost components differs among the two carrier groups; the percentage of total cost incurred in aircraft-traffic servicing seems to be higher for the nationals than for majors.
\end{abstract}

INTRODUCTION

The impacts of airline deregulation have been the subject of considerable research. The work generally falls into two categories. The first analyzes the impacts of deregulation on industry structure and conduct, including such subjects as marketing strategies, route structure, and patterns of market entry. The second strand of research focuses on the performance of the industry since deregulation, including efficiency, service quality, and convenience. This paper falls, to a large degree, within the second category of deregulation research. The paper compares the pre- and postderegulation cost structure of two groups of carriers: majors (formerly trunks) and nationals (formerly local service lines).

Most of the research in airline cost analysis has focused on developing causal models to explain changes in an airline's total operating cost as a result of changes in some selected explanatory variables. For instance, Caves and
Tretheway (1984) developed a total cost function to explain the difference in cost per unit between trunk and local service airlines. Kanafani and Hansen (1985) explored the effect of hubbing on airline operating cost. Toh and Higgens (1985) showed that airline network centrality (hubbing) does not guarantee profitability. Ghobrial (1991) found a positive relationship between airline profitability and hub dominance.

Unlike most previous studies that analyzed the effects of different variables on airline total cost or profitability, this paper examines the changes in airline cost structure pre- and post-deregulation. Economic theory suggests that there are substantialdifferencesbetween the cost characteristics of regulated (non-competitive) and non-regulated (competitive) industries. The airline industry is a "good test" case to validate these differences with empirical data. Specifically, we identify those functional areas in which airlines increased or decreased spending relative to other areas. We attempt to identify the effects of these changes on some related areas such as safety, labormanagement relations, and levels of service to passengers.

\section{CLASSIFICATION OF}

\section{AIRLINE OPERATING}

\section{COSTS}

There appear to be a number of systems to classify airline operating costs. Historically, the total operating costs have consisted of two major components: the direct operating costs and the indirect operating costs. This classification system is commonly used by air carriers and manufacturers. The direct operating costs are those incurred as a necessary result of, and directly related to, flying the aircraft. The indirect operating costs are not directly related to the operation of the aircraft but are incurred as a result of operating services on the ground and the usual overhead expenditures associated with the management of a business. Simpson and Chan (1971) developed a slightly different classification in which they rearranged the carrier's reported expenses. 
The system consists of four categories: flight operating costs, ground operating costs, system operating costs, and system non operating costs.

The cost classification system used here is the one contained in FORM 41 of the Uniform System in which each cost item is represented by a four-digit number. The first two digits represent the functional classification; the last two digits represent the objective classification which provides more information. This functional classification consists of the following categories: flying operations, maintenance, aircraft-traffic servicing, promotion and sales, passenger servicing, general and administrative, depreciation-amortization, and transport-related expenses.

\section{METHODOLOGY}

In order to compare the airline cost structure pre- and post-deregulation, we developed a dummy-variable model. Lee et. al. (1987) used the same functional model to study the changes in market structure, conduct and performance of the railroad industry under deregulation. Ghobrial and Lee (1990) used a similar approach to compare trunk and local service line strategies and performance. The following model is equivalent to a standard statistical analysis of variance model, but is easier to use when testing the differences between group means; those differences are the critical measures for investigation. The general form of the dummy-variable model is given as:

Equation 1: average percentage of a particular cost component for local service lines before deregulation. Likewise, if $F$ and $Y$ have the value one, the

$$
C C_{i}=\alpha+\beta F_{i}+\phi Y+\varphi F_{i} Y+\varepsilon_{i}
$$

where:

$\mathrm{CC}_{\mathrm{i}}=\mathrm{a}$ functional cost component of an airline $i$ expressed as a percentage of its total operating cost.

$F_{i}=a$ dummy variable for the firm type which takes on the value one for major carriers (formerly trunks), and zero for nationals (formerly local service lines).

$Y=a$ dummy variable for the year which takes on the value one for observations under deregulation (e.g. after 1977), and zero before 1978.

$F_{i} Y=a$ dummy variable representing the combined effect of deregulation and firm size on the cost structure and is obtained by multiplying the two variables $F_{i}$ and $Y$.

$\alpha, \beta, \phi$ and $\varphi$ are the coefficients to be estimated, and $\varepsilon_{i}$ is the error term of estimation.

By assigning appropriate values for $F_{i}$ and $Y$ in Equation 1 , one can estimate the average percentage of a particular cost component of the total operating cost of an airline group. For instance, by placing $F$ and $Y$ equal to zero, the dependent variable (equal to $\alpha$ in this case) is the estimated dependent variable (equal to the sum of $\alpha+\beta$ $+\phi+\varphi$ in this case) is the average percentage of a particular cost component for the majors after deregulation. Interpretation of similar results can be made for different values of $F$ and $Y . A{ }^{~ " t "}$ test for coefficient $\beta$ tells us whether the difference in that particular cost component is statistically significant between majors and nationals before deregulation. Similarly, a " $t$ " test for coefficient $\phi$ indicates whether that cost component has changed significantly before and after deregulation for nationals. Finally, the coefficient $\varphi$ measures the difference between nationals and majors due solely to deregulation (Kmenta, 1986).

To estimate Equation 1 for different airline cost components, we obtained a cross-sectional time-series data for a number of majors and nationals. The data comprised 258 observations and covered a period from 1970 to 1988 . The data were retrieved from FORM 41 as stored on the computerized tapes of Reuters 
Table 1

Percentage of Cost Components of Selected Carriers in 1985

\begin{tabular}{||l|l|c|c|c|c||}
\hline Airline & \multicolumn{1}{|c|}{$\begin{array}{c}\text { Airline } \\
\text { Group }\end{array}$} & $\begin{array}{c}\text { Flying } \\
\text { Operations }\end{array}$ & Maintenance & $\begin{array}{c}\text { Aircraft- } \\
\text { Traffic } \\
\text { Servicing } \\
\%\end{array}$ & $\begin{array}{c}\text { Promotion } \\
\text { and Sales }\end{array}$ \\
\hline American & Major & 32.59 & 9.11 & 15.72 & $\%$ \\
Delta & Major & 34.30 & 7.43 & 17.66 & 18.54 \\
Eastern & Major & 32.53 & 10.16 & 16.79 & 17.21 \\
Northwest & Major & 38.60 & 8.74 & 16.15 & 16.42 \\
TWA & Major & 35.21 & 11.19 & 14.28 & 16.34 \\
United & Major & 33.45 & 11.45 & 13.52 & 16.23 \\
Western & Major & 36.37 & 9.13 & 16.46 & 18.25 \\
Frontier & National & 39.29 & 11.63 & 20.54 & 8.28 \\
Ozark & National & 33.93 & 9.73 & 20.45 & 15.78 \\
Piedmont & National & 34.73 & 8.99 & 17.35 & 18.82 \\
Republic & National & 34.72 & 9.35 & 18.13 & 17.53 \\
& & & & \\
\hline
\end{tabular}

Information Inc. For the purpose of demonstration, Table 1 shows the percentages of the largest four cost components for selected majors and nationals in 1985 . As can be seen in Table 1, the four cost components constitute roughly 75 percent of the total operating cost. Estimation of Equation 1 was, therefore, done on each of the four components shown in Table 1.

\section{RESULTS}

Using the cross-sectional time series data, Equation 1 was estimated as a linear regression model. The first run of estimation indicated the presence of a significant degree of first order serial correlation which was corrected by applying a CochraneOrcutt transformation. The results of estimating Equation
1 for each cost component as a dependent variable are shown in Table 2 through Table 5. The bottom section in each table shows the estimated percentage of the cost component for both majors and nationals before and after deregulation. This was obtained by substituting the estimated parameters $\alpha, \beta, \phi$ and $\varphi$ into Equation 1 and assigning the appropriate values for variables $F$ and $Y$.

The theory of public finance suggests that firms in a regulated environment have higher average cost curves than those in a deregulated environment. This is because firms in regulated industries are allowed to recover the costs plus a percentage of capital as profit. Entry into the markets in this case is controlled by licensing or some other discriminatory mechanism. With no competitive pressures, firms do not have strong incentives to control costs (Broadway, 1984). The airline industry was in this environment prior to deregulation. With the advent of competition, there should have been some attempts to control costs. Institutionally, many airlines adopted highly publicized cost cutting measures after deregulation. For example, given that labor costs are, by far, the largest controllable cost in the airline industry, many carriers began to implement strategies to cut their labor costs. These strategies included revised work rules, two-tier wage scales, furloughs, and establishment 
of non-unionized subsidiaries. In some cases labor costs also decreased due to increased labor productivity.

Table 2 shows the results of estimating Equation 1 for the flying operations cost-component. Expenses incurred in this category are directly related to flight operation of aircraft that include operations personnel to prepare the aircraft for assignment to an in-flight status. The coefficient of determination $\left(R^{2}\right)$ is very low, and the estimated coefficients in Table 2 appear to be statistically insignificant.

Despite the poor statistical significance of the estimation, one can see a declining trend in the majors' cost allocation to flying operations. This could be attributed to improvement in their efficiency as a result of adopting the hub-and-spoke structure and to concessions obtained from pilots and labor.

Maintenance expenses include two categories. The first is direct maintenance, which includes the costs of labor, materials, and outside services consumed directly in periodic maintenance operations and the maintenance, repair, and upkeep of airframes, aircraft engines, other flight equipment, and ground property and equipment. The second category is maintenance burden, which includes the overhead or general expenses of activities involved in the repair and upkeep of property and equipment in accordance with prescribed operational standards. It also includes expenses related to the administration of maintenance stocks and stores and the keeping of maintenance operations records. Table 3 shows a significant decrease in airline expenses allocation to maintenance. This amount decreased from 13.2 to 10.6 percent for majors, and from 16.2 to 11 percent for nationals. One can assume that following deregulation airlines have become more productive and utilized their equipment more efficiently. The decrease in labor costs in this category can be another reason for increased airline efficiency. In addition, the results of estimating the interaction coefficient $\varphi$ in the maintenance equation suggests that majors have been less successful in reducing their relative cost allocation to maintenance than nationals. This is not surprising; majors have bigger operations and are likely less flexible in their response to changing conditions.

The aircraft and traffic servicing cost component includes those expenses incurred on the ground to protect and control the movement of aircraft, to schedule and prepare aircraft operational crew for flight assignment, to handle and service passengers on the ground after issuance of documents establishing the air carrier's responsibility to provide air transportation, and to cover in-flight expenses of handling and protecting nonpassenger traffic including passenger baggage. Table 4 shows that, while no significant changes took place in the percentage of this cost component for majors, that percentage decreased by about 2 points for nationals. This could be attributed to some efficiency measures taken by some nationals to handle aircraft and traffic servicing and to the introduction of low-cost carriers. Examples include PeopleExpress (a new entrant) which had relatively low labor costs and utilized its employees to perform several different tasks including ticketing, passenger handling, and incabin passenger servicing. An examination of the tasks involved in this cost category indicates that a considerable amount of expense is fixed, regardless of the amount of traffic being handled. For example, the cost of leasing the ticketing and baggage claim areas, equipment used to service the aircraft, and a good part of labor costs are relatively fixed costs. Given the relatively high volume of passenger traffic and aircraft movement of majors, one would expect these carriers to enjoy some economies of scale, and thus the percentage of aircraft and traffic servicing cost component is lower for the majors than for the nationals. In addition, automation of some tasks included in this category can increase productivity and reduce labor 
Table 2

Estimation of Equation 1 for Flying Operations

\begin{tabular}{|c|c|c|}
\hline $\begin{array}{c}\text { Flying } \\
\text { Operations }\end{array}$ & $\begin{array}{l}\text { Coem- } \\
\text { cient }\end{array}$ & T-Statisties \\
\hline $\begin{array}{l}\text { Constant } \\
\text { Y } \\
\text { F } \\
\text { YF }\end{array}$ & $\begin{array}{r}31.800 \\
-0.900 \\
2.270 \\
-2.590 \\
\end{array}$ & $\begin{array}{r}18.00 \\
-0.50 \\
1.44 \\
-1.40 \\
\end{array}$ \\
\hline $\begin{array}{l}\text { R-Squared } \\
\text { Durbin-Watson }\end{array}$ & & \\
\hline $\begin{array}{l}\text { Trunks pre-deregulation } \\
\text { Majors post-deregulation } \\
\text { Locals pre-deregulation } \\
\text { Nationals post-deregulation }\end{array}$ & & $\begin{array}{l}34.07 \% \\
30.58 \% \\
31.80 \% \\
30.90 \%\end{array}$ \\
\hline
\end{tabular}

Table 3

Estimation of Equation 1 for Maintenance

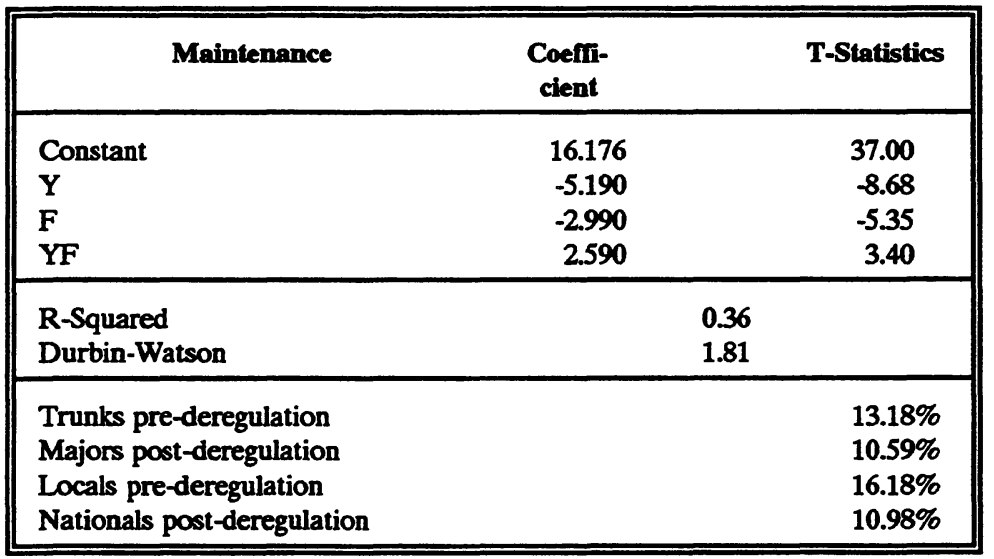

Table 4

Estimation of Equation 1 for Aircraft and Traffic Servicing

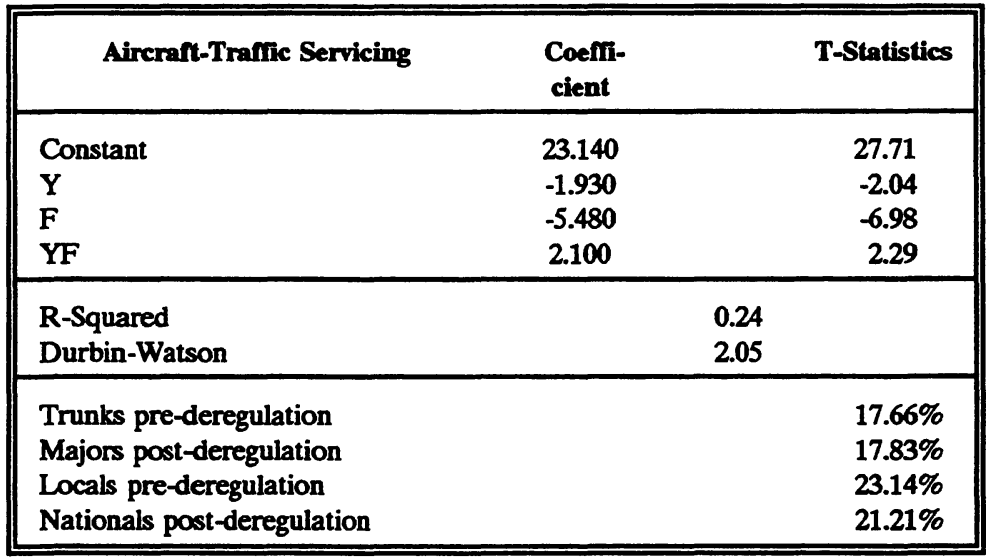

costs. The results reported in Table 4 appear to support the above discussion; on the average the percentage of aircraft and traffic servicing cost of the majors is about 4 percentage points lower than that of the nationals.

Finally, Table 5 reports the results of estimating Equation 1 for the promotion, sales, and advertising cost component. This category includes such functions as promoting the use of air transportation generally and creating a public preference for the services of a particular carrier. Costs incurred in this category include selling, advertising and publicity, reserving space, and developing airfares and flight schedules for publication. Given the complete marketing freedom granted to airlines followingderegulation, airlines have been able to inaugurate or discontinue service on short notice and to offer different discounted airfares. In such a dynamic environment, the role of communications between carriers and consumers becomes very important for successful operations of the carrier. One would, therefore, expect to find an increase in the allocation of expenses incurred in promotion and advertisement. The results in Table 5 support this finding; the percentage of expenses incurred in this cost category increased by 4 points for the majors and by 3 points for the nationals.

To summarize, it appears 
that airlines have reduced relative cost allocation to maintenance, while increasing the share of expenditures on promotion, sales and advertisement. The effect of the changes in airline cost structure on aviation safety, passengers levels of service, bankruptcies, and labormanagement relationship needs to be explored further.

LIMITATIONS OF THE STUDY

This study attempted to examine the changes in the cost structure of airlines preand post-deregulation. The results of estimating the dummy-variable model were interpreted in terms of airline strategies to reduce costs and improve efficiency. This section lists some of the limitations of the study that ought to be considered when drawing general conclusions

Table 5

Estimation of Equation 1 for Promotion, Sales, and Advertising

\begin{tabular}{|c|c|c|}
\hline Promotion and Sales & $\begin{array}{c}\text { Coem- } \\
\text { cient }\end{array}$ & T-Statistics \\
\hline $\begin{array}{l}\text { Constant } \\
\mathbf{Y} \\
\mathrm{F} \\
\mathrm{YF}\end{array}$ & $\begin{array}{r}11.120 \\
4.040 \\
0.907 \\
-0.127\end{array}$ & $\begin{array}{r}11.69 \\
4.21 \\
1.22 \\
-0.15\end{array}$ \\
\hline $\begin{array}{l}\text { R-Squared } \\
\text { Durbin-Watson }\end{array}$ & & \\
\hline $\begin{array}{l}\text { Trunks pre-deregulation } \\
\text { Majors post-deregulation } \\
\text { Locals pre-deregulation } \\
\text { Nationals post-deregulation }\end{array}$ & & $\begin{array}{l}12.03 \% \\
15.94 \% \\
11.12 \% \\
15.16 \%\end{array}$ \\
\hline
\end{tabular}

regarding airline cost structure:1.The model was estimated using cross-sectional time-series data from 1970 to 1988. During and after that time, many airlines have ceased operations or merged. For example, in 1991 six of the eleven carriers listed in Table 1 went bankrupt or were acquired by other carriers.
2. Unlike causal models, the dummy-variable model in this study does not capture the effects of some explanatory variables on changes in airline cost structure. It only tests the statistical significance of changes pre- and postderegulation. $\square$

Atef Ghobrial earned a Ph.D. in Transportation from the University of California at Berkeley, where he also earned a Master of Business Administration, and a Master of Science in Civil Engineering. An Associate Professor at Georgia State University, he directs the aviation administration program.

\section{REFERENCES}

Bailey, E., Graham, D. \& Kaplan, D. (1985). Deregulating the Airlines. Cambridge, Massachusetts: The MIT Press.

Brenner, M., Leet, J. \& Schott, E. (1985). Airline deregulation. Westport, Connecticut: Eno Foundation for Transportation Inc.

Broadway, R. \& Wildasin, D. (1984). Public sector economics (2nd ed.). Boston, Toronto: Little, Brown \& Co.

Caves, D., Christensen, L. \& Tretheway, M. (1984). Economies of density versus economies of scale: Why trunk and local service airline costs differ. Rand Journal of Economics, 15 (4), 471 489.

Douglas, G. \& Miller, J., III. (1974). Economic regulation of domestic air transport: Theory and practice. Washington, D.C.: Brookings Institution. 
Ghobrial, A. (1991). Competition for hub dominance: Some implications to airline profitability and enplanement share. The Journal of Aviation/Aerospace Education and Research, 2(1), 20-29. Ghobrial, A. \& Lee, T. (1990). Comparing trunk and local service lines strategies and performance. Transportation Quarterly, 44(2), 267-282.

Kanafani, A. (1985). Transportation demand analysis. New York: McGraw Hill.

Kanafani, A.\& Ghobrial, A. (1985). Airline hubbing - some implications for airport economics. Transportation Research, 19A(1), 15-27.

Kanafani, A. \& Hansen, M. (1985). Hubbing and airline costs. (Research Report UCB-ITS-RR-8512). Berkeley, California: Institute of Transportation Studies.

Kmenta, J. (1986). Elements of Econometrics, (2nd ed.) New York: Macmillan.

Lee, T., Baumel, C. \& Harris, P. (1987). Market structure, conduct and performance of the railroad industry under regulation. Transportation Journal, 26(4), 53-65.

Simpson, R. \& Chan, Y. (1971). A Structure for airline operating costs, (FTL Technical Memorandum 71-9). Cambridge: Massachusetts Institute of Technology.

Taneja, N. (1989). Introduction to civil aviation. Massachusetts/Toronto: Lexington Books.

Toh, R. \& Higgins, R. (1985). The impact of hub and spoke network centralization and route monopoly on domestic airline profitability. Transportation Journal. 24(4), 16-27.

Wells, A. (1989). Air transportation: A management perspective. Belmont, California: Wadsworth Publishing Company. 